\title{
Malaria in South America: a drug discovery perspective
}

\author{
Luiza R Cruz ${ }^{1 *}$, Thomas Spangenberg ${ }^{1}$, Marcus VG Lacerda ${ }^{2}$ and Timothy NC Wells ${ }^{1 *}$
}

\begin{abstract}
The challenge of controlling and eventually eradicating malaria means that new tools are urgently needed. South America's role in this fight spans both ends of the research and development spectrum: both as a continent capable of discovering and developing new medicines, and also as a continent with significant numbers of malaria patients. This article reviews the contribution of groups in the South American continent to the research and development of new medicines over the last decade. Therefore, the current situation of research targeting malaria control and eradication is discussed, including endemicity, geographical distribution, treatment, drug-resistance and diagnosis. This sets the scene for a review of efforts within South America to discover and optimize compounds with anti-malarial activity.
\end{abstract}

Keywords: South America, Malaria, Plasmodium, Plasmodium vivax, Treatment, Resistance, Drug discovery, Review

\section{Background}

Malaria is the tropical disease with the highest global mortality. In 2010, there were an estimated 216 million cases of malaria and 655,000 deaths worldwide, with children under five years and pregnant women the most vulnerable [1]. Over $81 \%$ of cases and $91 \%$ of deaths were in Africa, with the majority of the remaining being in India, Southeast Asia and South America.

South America includes 13 countries: Argentina, Bolivia, Brazil, Chile, Colombia, Ecuador, Guyana, Paraguay, Peru, Suriname, Uruguay, Venezuela and French Guiana. Most malaria cases are concentrated in the Amazon basin, with 580,000 reported in 2010, mainly in Brazil $(281,586)$ [2] and Colombia $(115,000)$ [3]. In 2010 only 240 deaths were registered, $0.085 \%$ of the global total. This low number reflected a combination of factors: the higher quality of health care, and the fact that the majority of cases are Plasmodium vivax rather than Plasmodium falciparum (estimated in 70\%). Plasmodium vivax mortality is often assigned to sequelae, such as haemolysis or lung inflammation, rather than the parasite itself $[4,5]$. Other species of malaria have been reported. Suriname [6] and French Guiana [7] report $12 \%$ and $6 \%$ Plasmodium malariae

\footnotetext{
*Correspondence: luizareiscruz@gmail.com; wellst@mmv.org

${ }^{1}$ Medicines for Malaria Venture, 20 route de Pré-Bois, Geneva CH 1215, Switzerland

Full list of author information is available at the end of the article
}

infections respectively, although this may be an underestimate resulting from difficult diagnosis in thick-smear blood or rapid tests.

Malaria has been a long-term health issue in South America. Throughout the 20th Century, the continent underwent a rapid and disorganized development and settlement process, leading to a population migration. In the Amazon basin, with increased prospecting for minerals and agricultural projects [8,9], work opportunities surged. This led to an increase in malaria prevalence and incidence in the 1970s and 1980s [10], a trend that is only now starting to be reversed [11].

South America, with its large biodiversity, has also played a key role in the identification of new medicines to combat malaria. The active cinchona bark, which led to the purification of quinine was first identified in Peru [12], and lapachol, the forerunner of atovaquone, also came from the Amazon basin [13]. This raises the question as to whether there are other natural products that could be useful in malaria. In addition, South America has an excellent scientific and clinical base, which can continue to support the discovery and development of new therapeutics. This review provides an overview of malaria in South America, focusing on progress in drug discovery, and highlighting critical future areas where the continent can support the malaria eradication agenda.

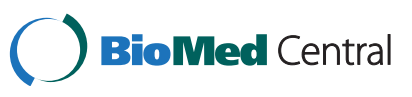

(C) 2013 Cruz et al.; licensee BioMed Central Ltd. This is an Open Access article distributed under the terms of the Creative Commons Attribution License (http://creativecommons.org/licenses/by/2.0), which permits unrestricted use, distribution, and reproduction in any medium, provided the original work is properly cited. 


\section{Malaria in South America}

The endemicity of malaria can be divided into three levels: high risk, if the annual parasite incidence (API) is higher than $1 \%$ of the inhabitants; medium risk, when it is 0.1 to $1 \%$ and low risk where it is less than $0.1 \%$ [11], (see Figure 1).

Of all the South American countries, Uruguay and Chile are malaria free, with no mosquito-transmitted infections. Argentina and Paraguay are progressing towards elimination [1]. The remainder of the continent shows a broad distribution of cases, with increasing frequency towards the tropics. Brazil, has an overall API of $0.16 \%$, reaching 0.6 to $0.7 \%$ in Amazonas and Acre [2]. On the other hand, in Colombia and Suriname $15 \%$ of the population live in areas with high transmission, and this number reaches $85 \%$ in French Guiana and Guyana where APIs of 35\% have been reported locally [7].

In the rainforest region, the primary vector species that transmits Plasmodium parasites is Anopheles darlingi [14-16], with other species such as Anopheles albitarsis, Anopheles albimanus, Anopheles aquasalis and Anopheles marajoara playing roles in transmission [17-19]. Anopheles gambiae was imported into South America from Africa in the transatlantic slave trade but was eliminated from the continent in the first half of the 20th Century [20,21].
Anopheles darlingi is an efficient vector, preferring humans over animals, and with a high susceptibility to Plasmodium infection [16]. Although nets are important, they are not sufficient, since many vectors have peak-biting hours before bedtime $[22,23]$ and in addition not all families have appropriate numbers of bed nets.

The standard treatment for uncomplicated $P$. falciparum malaria is artemisinin-based combination therapy (ACT), as recommended by the World Health Organization (WHO) [24], outlined in Figure 2. Chloroquine (CQ) is still effective for P. vivax in many countries. However, the Amazon Network for the Surveillance of Antimalarial Drugs Resistance (RAVREDA, Red Amazónica de Vigilancia de la Resistencia a los Antimaláricos) reported 10\% resistance to chloroquine in Amazonas, Brazil [25]. Primaquine is the standard therapy for preventing relapses of $P$. vivax, although there are issues with compliance to the 14-day regimen and a risk of haemolysis in G6PDdeficient subjects. Studies in Brazil showed that primaquine failed to prevent relapses in $24.5 \%$ of cases [26]. Whether this is true resistance to the drug or lack of compliance is not clear. It has been suggested that an increased dosage of primaquine is required for South America [27], and Brazil and Peru have recently shifted from 14 days of $0.25 \mathrm{mg} / \mathrm{kg} /$ day to seven days of $0.5 \mathrm{mg} / \mathrm{kg} /$ day. G6PD deficiency was
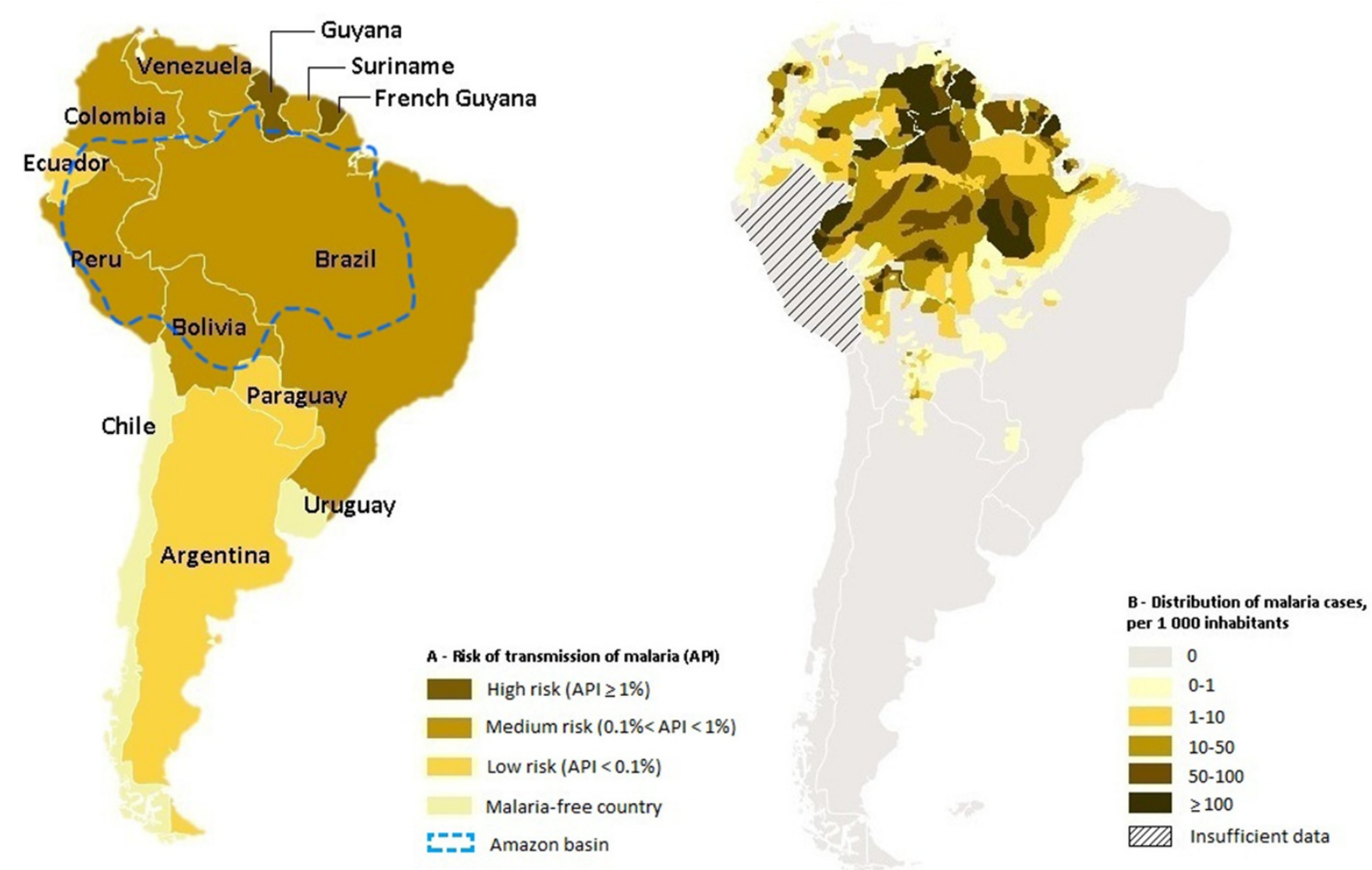

Figure 1 Incidence and risk of transmission of malaria. A- Risk of transmission of malaria, classified by country, in 2010. The dashed blue lines delimit the Amazon basin. B- Distribution of malaria cases in the Amazon basin, in 2010 (based on the WHO World Malaria Report 2011). 


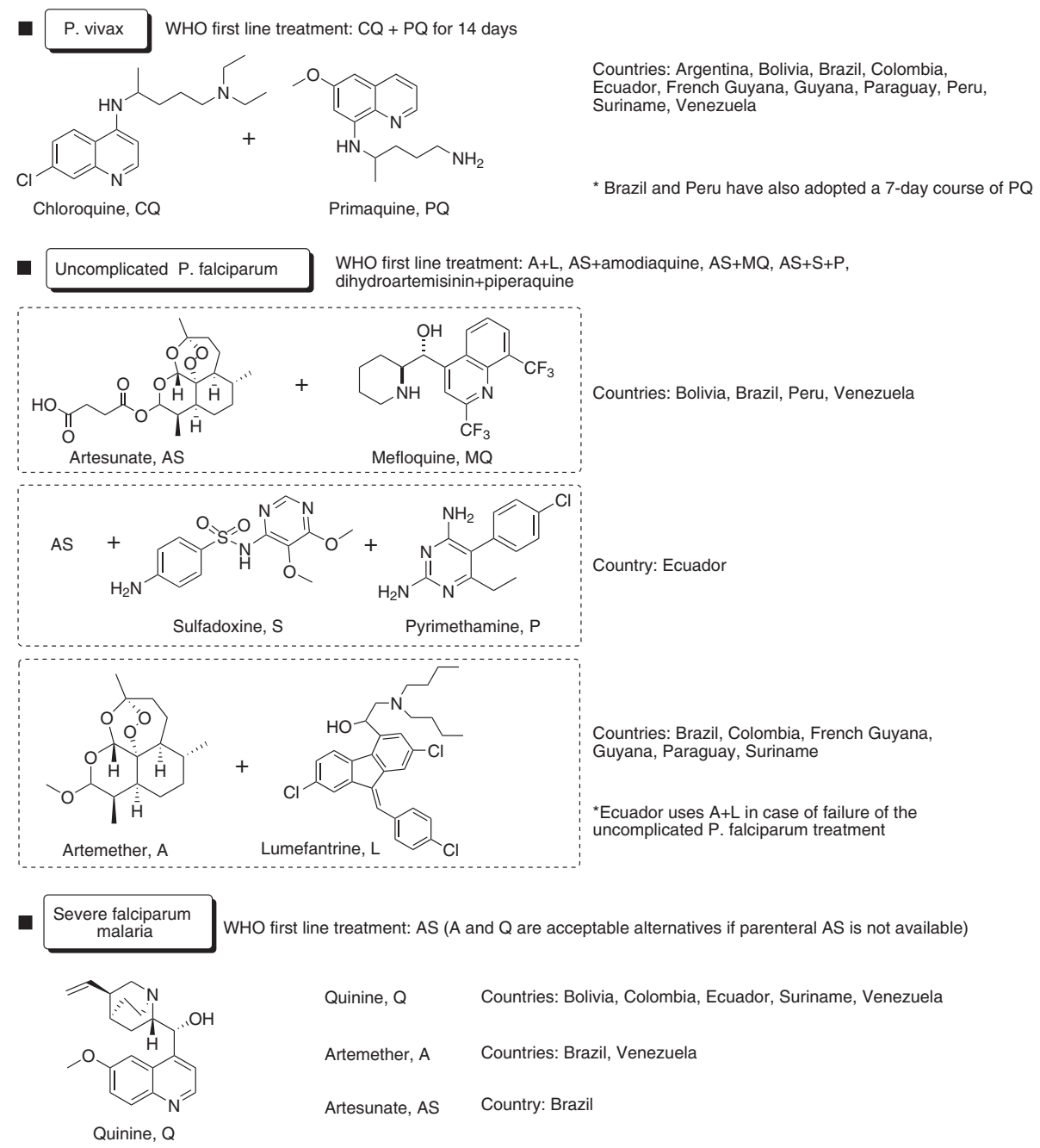

Figure 2 Malaria treatment. Standard treatment of malaria in South America according to the Ministries of Health from each country and to WHO guidelines for the treatment of various forms of malaria. There is also severe vivax malaria, for which the treatment should be similar to that used in the treatment of severe malaria caused by Plasmodium falciparum.

detected at 3\% prevalence in Manaus, Brazil [28] and was predominantly the mild $\mathrm{A}^{-}$form. In Buenaventura, Colombia, where a higher proportion of the population has African origins, prevalence of the mild $\mathrm{A}^{-}$form is $12 \%$ [29]. An improved version of primaquine, developed originally by the Walter Reed Army Institute of Research (WRAIR), called tafenoquine, is under clinical development as a single-dose anti-relapse agent, but this is not expected to be launched before 2017. For severe falciparum malaria, most countries use parenteral quinine, although data from Africa and Asia support a shift to artesunate for injection [30], which has already been pioneered by Brazil.

\section{Search methodology}

A literature search was conducted in February and March 2012 to identify studies regarding malaria research activities in South America. The sources for published data were SciFinder Scholar, $\operatorname{PubMed}^{\circ}$ and LILACS $^{\circ}$. The date of publication considered spanned from January 2000 to February 2012. The following key words were used for the database search: malaria or anti-malarial. The search list was refined by country by means of the affiliation field. All papers describing any type of drug (based on medicinal chemistry, natural products or other approaches) were selected. Only research showing either in vitro or in vivo activities of molecules was considered. In addition, the database Thomson Pharma ${ }^{\circ}$ was screened for clinical trials' protocols conducted within the continent. Papers regarding drug discovery research were divided into two groups: those covering natural products (divided into plant extracts and isolated substances) and those covering studies of new synthetic drug compounds. 


\section{Results}

\section{Natural products}

Pharmacognosy is the study of naturally occurring molecules with medicinal properties. Plant-derived compounds have been the backbone of the anti-malarial class of drugs over the last centuries, and two emerged from South America. Quinine is the active ingredient in cinchona tree bark in Peru and was purified in 1820, becoming the first disclosed compound with known antimalarial activity. Lapachol, belonging to the chemical class of naphthoquinones, was first isolated from Tabebuia avellanedae in 1882 and used to treat fever and malaria in the 19th Century in South America. A third natural product, artemisinin, was isolated by Chinese scientists from Artemisia annua. These natural products have served as starting points for medicinal chemistry optimization. Chloroquine was designed based on quinine, massively reducing the frequency of administration, and paving the way for a whole new generation of aminoquinolines and amino-alcohols. The chemical optimization from lapachol to atovaquone gave new molecules with more reliable oral bio-availability, allowing them to be used in prophylaxis. Modifying artemisinin to artesunate massively improved solubility (Figure 3), but has also led to the design of new improved endoperoxides such as OZ439 which is currently in Phase II trial to evaluate its efficacy and stability in malaria patients [31]. These improved molecules have been used to treat hundreds of millions of patients over the last century.

South America has a long tradition of studies of natural products based on two approaches: the biological evaluation of traditional medicines and the identification of plants (or organisms) with differences in secondary metabolism [32]. The natural products identified (pharmacognosy) are shown on Table 1. A cut-off of approximately $\mathrm{EC}_{50}$ of $1 \mu \mathrm{g} / \mathrm{mL}(1 \mu \mathrm{M}$ where the active ingredient is well characterized) was used based on the experience that almost $0.5 \%$ of chemical diversity is active at this level [33]. The structures of molecules are shown in Figure 4.

Thus, only five purified compounds (Figure 4) have been identified from these efforts. Studies of Bowdichia virgiloides, a plant used by the Tacana indigenous group as a traditional medicine for the relief of high fever, produced alkaloid 1 (ormosanine), having an $\mathrm{EC}_{50}=5 \mu \mathrm{g} / \mathrm{mL}$ against F32. In vivo, the extract showed 51\% suppression of parasites in mice at $100 \mathrm{mg} / \mathrm{kg}$, but was toxic at $250 \mathrm{mg} / \mathrm{kg}$. Baccharis dracunculifolia is broadly used in traditional medicine in Brazil, in inflammatory and gastrointestinal diseases. Although the total extract was inactive, the isolated the triterpenoid 2 showed anti-malarial and antileishmanial activity. In vitro screening of substances isolated from the Brazilian folk medicines identified neosergeolide 3, from Picrolemma spruce, which inhibits $\mathrm{K} 1$ with an impressive $\mathrm{EC}_{50}=2 \mathrm{nM}$; and, the aryltetralone 4 from Holostylis reniformis, with an $\mathrm{EC}_{50}=20 \mathrm{nM}$; both are claimed to have good therapeutic window against hepatocytes. Further testing of these compounds would be needed to assess their strengths and weaknesses. The 4nerolidylcatechol 5 was isolated from another traditional Amazonian treatment of malaria, Piper peltatum and shown to have an $\mathrm{EC}_{50}$ between 50 and $830 \mathrm{ng} / \mathrm{ml}$. Catechol 5 was also independently isolated from Pothomorphe peltata as shown in Table 1.

\section{Medicinal chemistry}

Medicinal chemistry approaches start from the knowledge of a structure combined with biological activity. Such starting points can be found from screening efforts (for example, pharmaceutical diversity or natural products against a biochemical target or whole cell), de novo design or from a published active, which can then act as a starting point for optimization. The molecules that have been identified from various sources against malaria with relevant endpoints and published within the South American
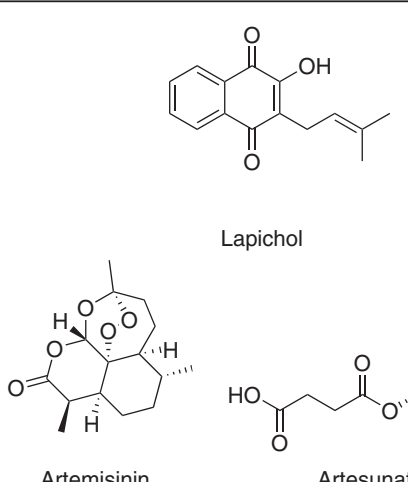

Lapichol
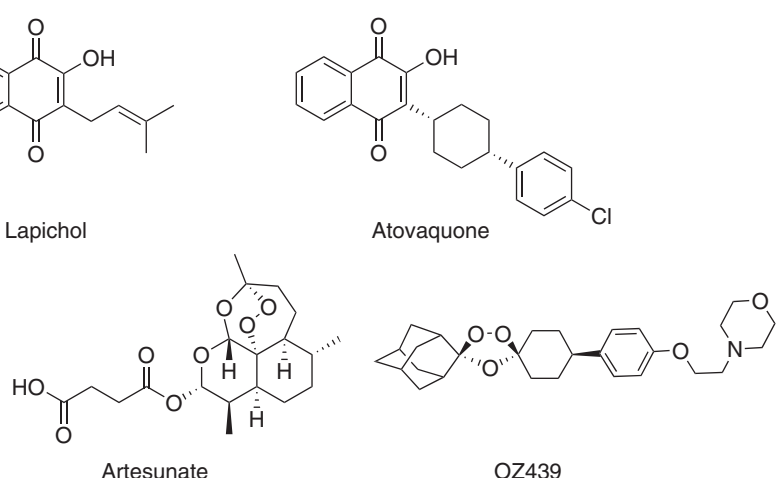

Figure 3 Structures of lapachol, atovaquone, artemisinin, artesunate and OZ439. Lapachol and artemisinin are examples of plant-derived compounds that originated anti-malarial compounds. Changes on these compounds gave atovaquone and artesunate, respectively. Additionally, OZ439 was inspired by artemisinin. 
Table 1 Summary of pharmacognosy studies

\begin{tabular}{|c|c|c|c|c|}
\hline Compound & Authors & Plant with the lowest $I C_{50}$ & Type & $\mathrm{IC}_{50}$ (P. falciparum strain) \\
\hline \multirow[t]{2}{*}{1} & Bravo et al. [34] & Bowdichia virgiloides & Extracts & $1.0 \mu \mathrm{g} / \mathrm{mL}$ \\
\hline & & & Isolated substances & $5 \mu \mathrm{g} / \mathrm{mL}$ (F32 and Indo) \\
\hline- & Deharo et al. [35] & Bowdichia virgiloides & Extracts & $1 \mu \mathrm{g} / \mathrm{mL}(\mathrm{F} 32)$ \\
\hline \multirow[t]{2}{*}{2} & da Silva Filho et al. [36] & Baccharis dracunculifolia & Extracts & $13 \mu \mathrm{g} / \mathrm{mL}$ \\
\hline & & & Isolated substances & $0.8 \mu \mathrm{g} / \mathrm{mL}$ (W2 e D6) \\
\hline 3 & de Andrade-Neto et al. [37] & Picrolemma spruce & Isolated substances & $0.002 \mu \mathrm{M}(\mathrm{K} 1)$ \\
\hline 4 & de Andrade-Neto et al. [38] & Holostylis reniformis & Isolated substances & $0.20 \mu \mathrm{M}$ (field isolate) \\
\hline- & Kayano et al. [39] & Caesalpina pluviosa & Extracts & $0.59 \mu \mathrm{g} / \mathrm{mL}(3 \mathrm{D} 7)$ \\
\hline 5 & Rocha e Silva et al. [40] & Piper peltatum & Isolated substances & $0.05-2.11 \mu \mathrm{g} / \mathrm{mL}(\mathrm{M} 1)$ \\
\hline 5 & Pinto et al. [41] & Pothomorphe peltata & Isolated substances & $0.67 \mu \mathrm{M}(\mathrm{K} 1)$ \\
\hline- & Garavito et al. [42] & Remijia peruviana & Extracts & $0.85 \mu \mathrm{g} / \mathrm{mL}(\mathrm{FcB} 2)$ \\
\hline- & Debenedetti et al. [43] & Buddleja globosa & Extracts & $8.9 \mu \mathrm{g} / \mathrm{mL}(\mathrm{K} 1)$ \\
\hline- & Baelmans et al. [44] & Caesalpina pluviosa & Extracts & $8 \mu \mathrm{g} / \mathrm{mL}(\mathrm{D} 2)$ \\
\hline \multirow[t]{2}{*}{-} & Flores et al. [45] & Caesalpina pluviosa & Extracts & $3.4 \mu \mathrm{g} / \mathrm{mL}$ \\
\hline & & & Isolated substances & Inactive (F32) \\
\hline- & Ibáñez-Calero et al. [46] & Rumex obtusifolius & Isolated substances & $71 \mu \mathrm{g} / \mathrm{mL}^{\mathrm{i}}$ \\
\hline- & Muñoz et al. [47] & Sparanttanthelium amazonum & Extracts & $2 \mu \mathrm{g} / \mathrm{mL}(\mathrm{F} 32)$ \\
\hline- & Muñoz et al. [48] & Swietenia macrophylla & Extracts & $73 \%{ }^{\mathrm{ii}}$ \\
\hline- & Muñoz et al. [49] & Tripodanthus acutifolis & Extracts & $98 \%^{\mathrm{iii}}$ \\
\hline- & Costa et al. [50] & Montrichardia linifera & Extracts & $11.7 \mu \mathrm{g} / \mathrm{mL}(\mathrm{W} 2)$ \\
\hline \multirow[t]{2}{*}{-} & da Silva Filho et al. [51] & Nectandra megapotamica & Extracts & $28 \mu \mathrm{g} / \mathrm{mL}$ \\
\hline & & & Isolated substances & $3.8 \mu \mathrm{g} / \mathrm{mL}$ (D6) \\
\hline- & de Andrade-Neto et al. [52] & Bidens pilosa & Extracts & $3.1 \mu \mathrm{g} / \mathrm{mL}$ (D6) \\
\hline- & de Andrade-Neto et al. [53] & Remijia ferruginea & Extracts & $48 \%{ }^{i v}$ \\
\hline- & de Mesquita et al. [54] & Matayba guianensis & Isolated substances & $2.5 \mu \mathrm{g} / \mathrm{mL}(\mathrm{FcB} 1)$ \\
\hline \multirow[t]{2}{*}{-} & Dolabela et al. [55] & Esenbeckia febrifuga & Extracts & $15.5 \mu \mathrm{g} / \mathrm{mL}$ \\
\hline & & & Isolated substances & $75.3 \mu \mathrm{g} / \mathrm{mL}(\mathrm{W} 2)$ \\
\hline- & Estevam et al. [56] & Ouratea nitida & Extracts & $51.04 \%{ }^{v}$ \\
\hline- & Fischer et al. [57] & Xylopia emarginata & Extracts & $3.3 \mu \mathrm{g} / \mathrm{mL}(\mathrm{PA})$ \\
\hline- & Morais et al. [58] & Pentacalia desiderabilis & Isolated substances & $7.82 \mu \mathrm{g} / \mathrm{mL}(\mathrm{K} 1)$ \\
\hline- & Oliveira et al. [59] & Bidens pilosa & Extracts & $38 \%^{\mathrm{vi}}$ \\
\hline- & Sá et al. [60] & Physalis angulata & Isolated substances & $2.2 \mu \mathrm{M}(\mathrm{W} 2)$ \\
\hline \multirow[t]{2}{*}{-} & Uchôa et al. [61] & Cecropia pachystachya & Extracts & $66 \%^{4}$ \\
\hline & & & Isolated substances & $58 \%$ vii \\
\hline- & Loyola et al. [62] & Azorella compacta & Isolated substances & $60 \%$ viii \\
\hline- & Pabón et al. [63] & Solanum nudum & Isolated substances & $21 \mu \mathrm{M}(\mathrm{FcB} 2)$ \\
\hline- & Céline et al. [64] & Siparuna aspera & Extracts & $6.4 \mu \mathrm{g} / \mathrm{mL}$ (FCR-3) \\
\hline- & Ruiz et al. [65] & Minquartia guianensis & Extracts & $4.2 \mu \mathrm{g} / \mathrm{mL}$ (FCR-3) \\
\hline
\end{tabular}

${ }^{\mathrm{i}}$ Inhibition of biocrystallization of ferriprotoporphyrin IX.

ii Percentage of inhibition of parasite growing (dose: $250 \mathrm{mg} / \mathrm{kg}$ ).

iii Percentage of inhibition of parasite growing (at $10 \mu \mathrm{g} / \mathrm{mL}$ ).

iv Reduction of parasitaemia (dose: $1000 \mathrm{mg} / \mathrm{kg}$ ).

${ }^{v}$ Activity tested against Plasmodium berghei in mice (dose: $1000 \mathrm{mg} / \mathrm{kg}$ ).

${ }^{v i}$ Reduction of parasitaemia at day 5 (dose: $250 \mathrm{mg} / \mathrm{kg}$ ).

vii Percentage inhibition of parasitaemia in relation to untreated infected mice on day 8 after malaria infection (doses: 250 and $15 \mathrm{mg} / \mathrm{kg}$ respectively).

viii Activity in mice measured by the growth of inhibition (dose: $10 \mathrm{mg} / \mathrm{kg} /$ day). 


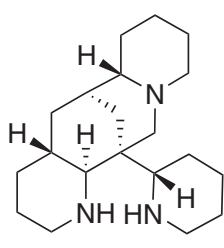

1<smiles></smiles>

2

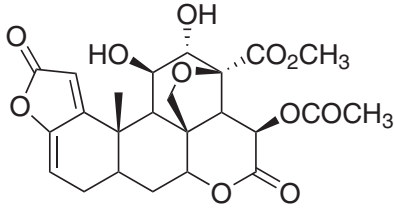

3<smiles>COc1ccc(C2c3cc(OC)c(OC)cc3C(=O)[C@@H](C)C2C)cc1OC</smiles>

4<smiles>C=CC(C)(CC/C=C(\C)CCC=C(C)C)c1ccc(O)c(O)c1</smiles>

5

Figure 4 Structures of plant-derived compounds. These compounds show activities $\left(E C_{50}\right)$ below $1 \mu \mathrm{M}$.

medicinal chemistry community are summarized in Table 2, and in addition, their structures are presented in Figure 5. Studies characterizing the spectroscopy of previously described molecules, or studies on marketed antimalarials have not been included.

Those compounds having $\mathrm{EC}_{50}$ values less than $1 \mu \mathrm{g} / \mathrm{ml}$ (with a square box around) are discussed further as this is the typical potency cut-off required for "Validated Hits" the starting points for drug discovery projects, as considered by the Medicines for Malaria Venture $[98,99]$.

New pyrazolylnaphthoquinones (heterocyclic naphthoquinones, building on the atovaquone template bearing 3aminopyrazole rings) and 5-aminoisoxazole analogues showed activity against $P$. falciparum, Trypanosoma cruzi and Trypanosoma brucei. The 5-aminoisoxazole analogue 6 showed an $\mathrm{EC}_{50}$ of $110 \mathrm{ng} / \mathrm{mL}$ and an independent naphthoquinone, 7, demonstrated an $\mathrm{EC}_{50}$ of $30 \mathrm{nM}$ against FcB1. A novel piperazinyl/steroidal analogue, 11, also inhibited FcB1 with an $\mathrm{EC}_{50}$ of $0.08 \mu \mathrm{M}$. Pinheiro et al. used a multivariate and quantum mechanical method to analyse 15 dihydroartemisinin derivatives and the most potent compound, 13, showed an $\mathrm{EC}_{50}$ of $0.05 \mathrm{ng} / \mathrm{mL}$, over 10-fold more potent than the reported values for dihydroartemisinin. Two papers describe chalcone derivatives: the electrophilic chloro-vinyl sulphone 21 showed an $\mathrm{EC}_{50}$ of $0.025 \mu \mathrm{M}$ against $\mathrm{W} 2$ and the sulphonamide chalcone 22 showed an $\mathrm{EC}_{50}$ of $0.48 \mu \mathrm{M}$. Finally, approaches to aminoquinolines identified the derivative 24 with an $\mathrm{EC}_{50}$ of $48 \mathrm{nM}$, against the 3D7 strain; and new heterocyclic hybrids based on the chloroquine and thiazolidinone scaffolds such as 25 have an $\mathrm{EC}_{50}$ of $0.25 \mu \mathrm{M}$.

\section{Discussion}

In South America, the morbidity and mortality due to malaria is much less significant than in Africa. However, the continent has historically been the source of two of the major classes of drugs against malaria, and the combination of both biodiversity and skilled medicinal chemists could position the continent in a leading position in the search for the new medicines needed for malaria eradication. The current biggest threat in the fight against malaria is the emerging resistance to artemisinin derivatives [100,101]. Artemisinin derivatives within ACT are the most widely used anti-malarials. Even though there has been a concerted attempt to protect them against resistance by banning artesunate monotherapy for uncomplicated disease, the first signs of artemisinin resistance or insensitivity have been described in Cambodia [102] and more recently in Thailand [103]. There is a great need for new combination therapy, replacing the three days' dosing of ACT with a single dose that also prevents transmission and relapse (in the case of P. vivax or Plasmodium ovale) [104].

Pharmacognosy has continued to identify new active structures [105]. However, the progress in bringing forward new medicines from these structures and extracts is extremely difficult. Where such molecules are reported to have interesting properties from observational studies, then it is important to confirm these observations in carefully controlled human clinical studies [106]. Also, it is possible that the active principle is a metabolite from the original extract, and so analysis of plasma samples is also important in understanding and identifying the active species [33]. Secondary metabolites are usually thought to play a key role in protection against predators, and therefore could be expected to be cytotoxic. Screening for activity in early safety assays is therefore of paramount concern here. Ultimately the goal of such experiments is to identify new starting points for medicines, similar to the way that quinine 
Table 2 Summary of medicinal chemistry studies

\begin{tabular}{|c|c|c|c|c|}
\hline Compound & Authors & Target & Chemical class & Lowest IC $\mathrm{C}_{50}$ (strain) \\
\hline 6 & Sperandeo and Brun [66] & - & $\begin{array}{l}\text { Pyrazolylnaphthoquinones, 5- } \\
\text { aminoisoxazole }\end{array}$ & $0.11 \mu \mathrm{g} / \mathrm{mL}(\mathrm{K} 1)$ \\
\hline 7 & Silva et al. [67] & - & 1,4-naphthoquinones & $0.03 \mu \mathrm{M}(\mathrm{FcB} 1)$ \\
\hline 8 & Charris et al. [68] & $\beta$-haematin & Thieno(2,3-b)quinoline & $74.42 \%^{1}$ \\
\hline 9 & Cunico et al. [69] & Aspartyl protease & Hydroxyethylpiperazines & $4.6 \mu \mathrm{M}(3 \mathrm{D} 7)$ \\
\hline 10 & Cunico et al. [70] & Aspartyl protease & Hydroxyethyylpiperazines & $5.1 \mu \mathrm{g} / \mathrm{mL}(\mathrm{W} 2)$ \\
\hline 11 & Gnoatto et al. [71] & $\beta$-haematin & Piperazine, 3-acetylursolic acid & $0.08 \mu \mathrm{M}(\mathrm{FcB} 1)$ \\
\hline 12 & de Sá et al. [72] & & Betulinic acid & $5.99 \mu \mathrm{M}(\mathrm{W} 2)$ \\
\hline 13 & Pinheiro et al. [73] & - & Sesquiterpenes & $\begin{array}{l}0.05 \mathrm{ng} / \mathrm{mL} \text { (P. falciparum } \\
\text { mefloquine resistant) }\end{array}$ \\
\hline 14 & Barbosa et al. [74] & - & Ozonides & $13.6 \mu \mathrm{g} / \mathrm{mL}$ \\
\hline 15 & Oliveira et al. [75] & Cysteine proteases & Semicarbazone, Thiosemicarbazone & $7.2 \mu \mathrm{M}(\mathrm{W} 2)$ \\
\hline 16 & Camacho et al. [76] & $\beta$-haematin & Benzimidazole-5-carbohydrazides & $8.43 \mu \mathrm{M}$ \\
\hline 17 & Corrales et al. [77] & $\begin{array}{l}\text { Hypoxanthine-guanine } \\
\text { phosphoribosyltransferase }\end{array}$ & 6-thiopurine Steroids & $82 \%^{1}$ \\
\hline 18 & Barazarte et al. [78] & $\beta$-haematin & $\begin{array}{c}\text { Pyrazolo and pyrimido benzothiazine } \\
\text { dioxide }\end{array}$ & $92.32 \%^{2}$ \\
\hline 19 & Barazarte et al. [79] & $\beta$-haematin & Benzothiazines & $78.17 \%^{2}$ \\
\hline 20 & Vellasco Junior et al. [80] & Aspartyl protease & Thioetherhydroxyethyl, Sulfonamides & $15 \mu \mathrm{M}(\mathrm{W} 2)$ \\
\hline 21 & Dominguez et al. [81] & $\beta$-haematin & Chlorovinyl sulfones & $0.025 \mu \mathrm{M}(\mathrm{W} 2)$ \\
\hline 22 & Dominguez et al. [82] & $\beta$-haematin & Sulfonamide chalcones & $0.48 \mu \mathrm{M}(\mathrm{W} 2)$ \\
\hline 23 & León et al. [83] & $\begin{array}{c}\text { Glucose metabolism } \beta \text { - } \\
\text { haematin }\end{array}$ & Sulfonylureas & $1.2 \mu \mathrm{M}(\mathrm{W} 2)$ \\
\hline 24 & Arancibia et al. [84] & $\beta$-haematin & $\begin{array}{l}\text { Rhenium bioorganometalics, } \\
\text { Aminoquinoline }\end{array}$ & $0.048 \mu \mathrm{M}(3 \mathrm{D} 7)$ \\
\hline 25 & Rojas Ruiz et al. [85] & $\beta$-haematin & Aminoquinolines, thiazolidinone & $0.25 \mu \mathrm{M}(3 \mathrm{D} 7)$ \\
\hline 26 & Charris et al. [86] & $\beta$-haematin & E-2-quinolinylbenzo-cycloalcanones & $90 \%^{3}$ \\
\hline 27 & Vashist et al. [87] & $\beta$-haematin & Quinolone, 6-thiopurine & inactive \\
\hline 28 & de Souza et al. [88] & $\beta$-haematin & 4-aminoquinolines, platinum (II) complexes & $84 \%{ }^{4}$ \\
\hline 29 & Cunico et al. [89] & $\beta$-haematin & 4-aminoquinolines & $1.39 \mu \mathrm{g} / \mathrm{mL}(\mathrm{W} 2)$ \\
\hline 30 & Rodrigues et al. [90] & $\beta$-haematin & Quinoline & Active \\
\hline 31 & Domínguez et al. [91] & Cysteine protease falcipain & Quinolinyl chalcones & $19 \mu \mathrm{M}(\mathrm{FcB} 1)$ \\
\hline 32 & Ferrer et al. [92] & $\beta$-haematin & Chloroquinolines & $94.93 \%^{3}$ \\
\hline 33 & Navarro et al. [93] & $\beta$-haematin & Gold-chloroquine complexes & -5 \\
\hline 34 & Domínguez et al. [94] & Cysteine protease $\beta$-haematin & Phenylurenyl chalcones & $1.76 \mu \mathrm{M}$ \\
\hline 35 & $\begin{array}{l}\text { de Andrade-Neto et al. } \\
\text { [95] }\end{array}$ & - & Naphthoquinones, Phenazines & $1.67 \mu \mathrm{M}(\mathrm{W} 2)$ \\
\hline 36 & Hilário et al. [96] & - & 3-alkylpyridines alkaloids & $<3.38 \mu \mathrm{M}(\mathrm{W} 2)$ \\
\hline 37 & Rodrigues et al. [97] & $\beta$-haematin & Bisquinoline & $56.76 \%^{2}$ \\
\hline
\end{tabular}

${ }^{1}$ Percentage of inhibition of parasite growth ( $P$. berghei in mice) at day 9 (dose: $10 \mathrm{mg} / \mathrm{kg}$ ).

2 Inhibition of globin proteolysis (IGP) expressed as percentage.

${ }^{3}$ Inhibition of $\beta$-haematin synthesis (I $\beta H S$ ) expressed as percentage.

${ }^{4}$ Inhibition of parasite multiplication on days (dose: $25 \mathrm{mg} / \mathrm{kg}$ ).

${ }^{5}$ Activity expressed as $I C_{50}(C Q D P) / I C_{50}$ (complex).

and lapachol opened up new fields in previous centuries. Such approaches require long-term commitment, and hence the need to verify the original clinical observations.
The other approach to discover new drugs is to use medicinal chemistry, either with scaffolds already known to be effective against the parasite, or a target-based approach based on structural biology. The results of this 


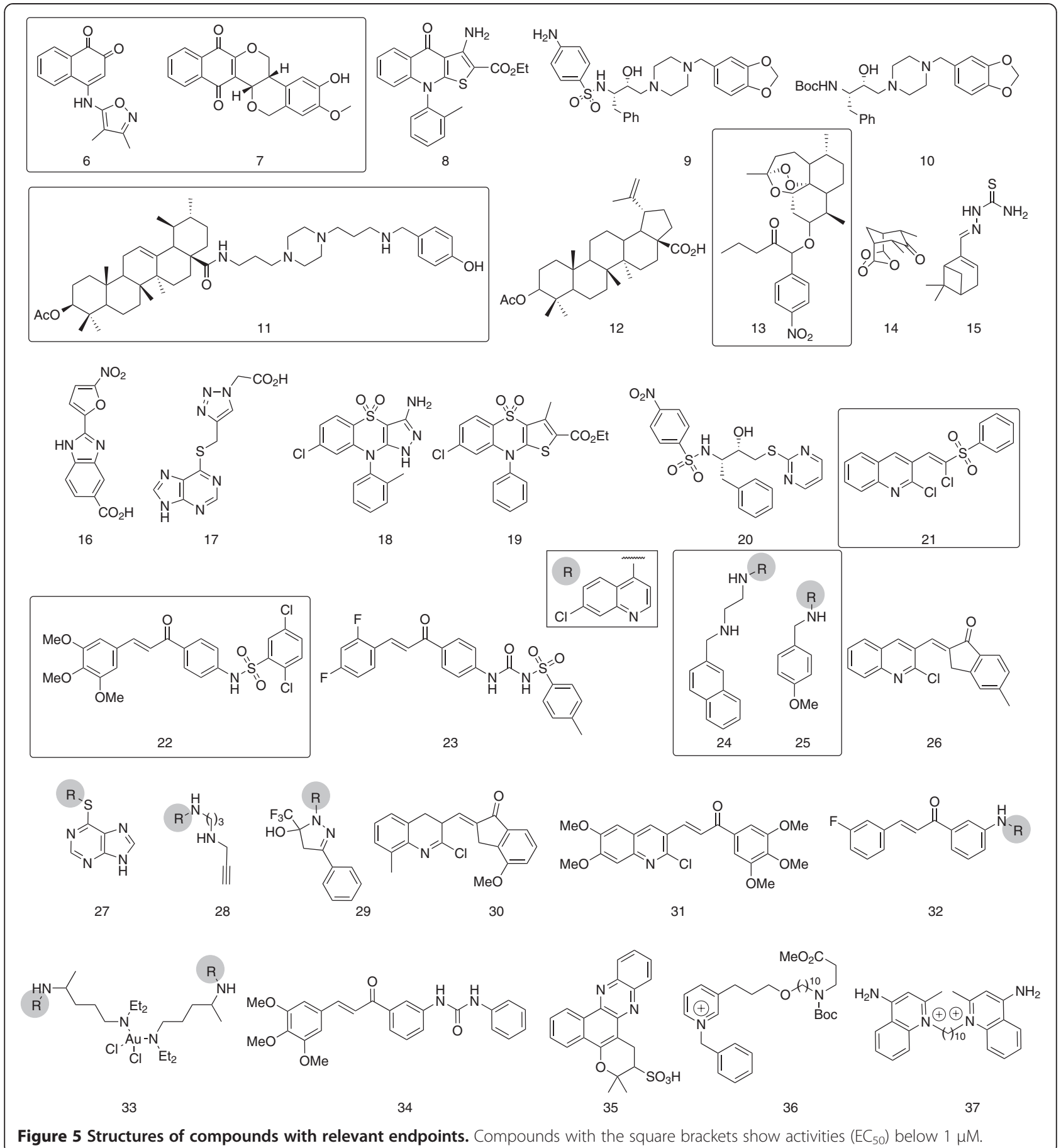

survey show that molecules coming from South American programmes are able to demonstrate innovative and active new structures. However over the last five years, the bar has been raised and a new challenge has been set as a result of the success of phenotypic screening. With over 20,000 structures of compounds active against the parasite deposited in the public domain $[107,108]$, it is important to benchmark the successes found in South America against these results. Clearly the prize no longer goes to compounds that simply kill the parasite in vitro, but to molecules that have good properties supporting excellent oral administration in patients, or perhaps equal artemisinins in speed of killing parasites [109], or have a very low propensity to resistance generation [110]. In the light of the malaria eradication agenda, it will be important also to know how these new molecules work in the different stages of the parasite lifecycle [111]. A molecule that could be shown to inhibit the dormant liver stages of $P$. vivax would clearly 
stand out from the crowd [112]. All of the tools are available to enable South American anti-malarial drug research to make these steps forward over the next five years, the challenge will be to put these together, and focus the agenda to the needs of the South American community.

\section{Conclusion}

Malaria continues to be a health issue, particularly $P$. vivax in the Amazon basin, and P. falciparum and mixed infections in northern countries. The natural diversity along with the indigenous folk medicines allows a great potential in the treatment and identification of new anti-malarial drugs, as happened with the South American compounds, lapachol and quinine. New molecules are being identified but their optimization for in vivo activity has been slow, arguing that more resource needs to be focused in these areas. In addition, the new assays for transmission and relapse of dormant liver stages need to be put into routine practice. If all this is put together, then South America can again play a leading role in the discovery of the next generation of therapeutics against malaria.

\section{Abbreviations}

ACT: Artemisinin-based combinations therapy; API: Annual Parasite Incidence; G6PD: Glucose-6-phosphate dehydrogenase; RAVREDA: Amazon Network for the Surveillance of Antimalarial Drugs Resistance; WHO: World Health Organization; WRAIR: Walter Reed Army Institute of Research.

\section{Competing interests}

The authors declare that they have no competing interests.

\section{Authors' contributions}

LRC and TS conceived the review. LRC performed the bibliographical research, retrieved the references and drafted the manuscript. TS, MVGL and TNCW critically revised the document. All authors read and approved the final manuscript.

\section{Acknowledgements}

We acknowledge the Medicines for Malaria Venture, especially Jeremy Burrows for critical comments on the manuscript. The authors are also grateful to Carlos Morel and Simon Campbell. MVGL is a level 2 Fellow from the National Council for Scientific and Technological Development (CNPq).

\section{Author details}

'Medicines for Malaria Venture, 20 route de Pré-Bois, Geneva CH 1215, Switzerland. ${ }^{2}$ Fundação de Medicina Tropical Dr Heitor Vieira Dourado, Av Pedro Teixeira, 25, Manaus, Amazonas 69040-000, Brazil.

Received: 5 March 2013 Accepted: 15 May 2013

Published: 24 May 2013

\section{References}

1. WHO: World Malaria Report 2011. Geneva: World Health Organization; 2011

2. Brazil, Ministry of Health: Portal da Saúde; 2012 [http://portalsaude.saude. gov.br/portalsaude/index.cfm]

3. Rodríguez JCP, Uribe GA, Araújo RM, Narváez PC, Valencia SH: Epidemiology and control of malaria in Colombia. Mem Inst Oswaldo Cruz 2011, 106:114-122.

4. Anstey NM, Russel B, Yeo TW, Price RN: The pathophysiology of vivax malaria. Trends Parasitol 2009, 25:220-227.

5. Lacerda MV, Fragoso SC, Alecrim MG, Alexandre MA, Magalhães BM, Siqueira AM, Ferreira LC, Araújo JR, Mourão MP, Ferrer M, Castillo P, MartinJaular L, Fernandez-Becerra C, del Portillo H, Ordi J, Alonso PL, Bassat Q: Postmortem characterization of patients with clinical diagnosis of
Plasmodium vivax malaria: to what extent does this parasite kill? Clin Infect Dis 2012, 55:e67-e74.

6. Peek R, VAN Gool T, Panchoe D, Greve S, Bus E, Resida L: Drug resistance and genetic diversity of Plasmodium falciparum parasites from Suriname. Am J Trop Med Hyg 2005, 73:833-838.

7. Stefani A, Hanf M, Nacher M, Girod R, Carme B: Environmental, entomological, socioeconomic and behavioural risk factors for malaria attacks in Amerindian children of Camopi, French Guiana. Malar J 2011, 10:246.

8. Oliveira-Ferreira J, Lacerda MV, Brasil P, Ladislau JL, Tauil PL, Daniel-Ribeiro CT: Malaria in Brazil: an overview. Malar J 2010, 1:15.

9. Alvarez A: Malaria and the emergence of rural health in Argentina: an analysis from the perspective of international interaction and co-operation. Can Bull Med Hist 2008, 25:137-160.

10. Carter R, Mendis KN: Evolutionary and Historical Aspects of the Burden of Malaria. Clin Microbiol Rev 2002, 15:564-594.

11. Pan American Health Organization: Report on the situation of malaria in the Americas, 2008. Washington, D.C: PAHO; 2010. http://www2.paho.org/hq/ dmdocuments/2011/PAHO_ENG_Malaria_LR.pdf.

12. Achan J, Talisuna AO, Erhart A, Yeka A, Tibenderana JK, Baliraine FN, Rosenthal PJ, D'Alessandro U: Quinine, an old antimalarial drug in a modern world: role in the treatment of malaria. Malar J 2011, 10:144.

13. Hudson AT: Atovaquone - a novel broad-spectrum anti-infective drug. Parasitol Today 1993, 9:66-68.

14. Rutar T, Baldomar Salgueiro EJ, Maguire JH: Introduced Plasmodium vivax malaria in a Bolivian community at an elevation of 2,300 meters. Am J Trop Med Hyg 2004, 70:15-19.

15. Sutton PL, Neyra V, Hernandez JN, Branch OH: Plasmodium falciparum and Plasmodium vivax infections in the Peruvian Amazon: propagation of complex, multiple allele-type infections without super-infection. Am J Trop Med Hyg 2009, 81:950-960.

16. Magris M, Rubio-Palis $Y$, Menares C, Villegas L: Vector bionomics and malaria transmission in the Upper Orinoco River, Southern Venezuela. Mem Inst Oswaldo Cruz 2007, 102:303-311.

17. da Rocha JAM, de Oliveira SB, Póvoa MM, Moreira LA, Krettli AU: Malaria vectors in areas of Plasmodium falciparum epidemic transmission in the Amazon region, Brazil. Am J Trop Med Hyg 2008, 78:872-877.

18. Pinault $L L$, Hunter FF: New highland distribution records of multiple Anopheles species in the Ecuadorian Andes. Malar J 2011, 10:236.

19. Moreno JE, Rubio-Palis Y, Páez E, Pérez E, Sánchez V: Abundance, biting behaviour and parous rate of anopheline mosquito species in relation to malaria incidence in gold-mining areas of southern Venezuela. Med Vet Entomol 2007, 21:339-349.

20. Yalcindag E, Elguero E, Arnathau C, Durand P, Akiana J, Anderson TJ, Aubouy A, Balloux F, Besnard P, Bogreau H, Carnevale P, D'Alessandro U, Fontenille D, Gamboa D, Jombart T, Le Mire J, Leroy E, Maestre A, Mayxay M, Ménard D, Musset L, Newton PN, Nkoghé D, Noya O, Ollomo B, Rogier C, Veron V, Wide A, Zakeri S, Carme B, Legrand E, Chevillon C, Ayala FJ, Renaud F, Prugnolle F: Multiple independent introductions of Plasmodium falciparum in South America. Proc Natl Acad Sci USA 2012, 109:511-516.

21. Silva LHP, Oliveira VEG: The malaria challenge: the Brazilian case and what can be expected from progress in genomics. Ciência \& Saúde Coletiva 2002, 7:49-63.

22. Magris M, Rubio-Palis Y, Alexander N, Ruiz B, Galván N, Frias D, Blanco M, Lines J: Community-randomized trial of lambdacyhalothrin-treated hammock nets for malaria control in Yanomami communities in the Amazon region of Venezuela. Trop Med Int Health 2007, 12:392-403.

23. Hill N, Lenglet A, Arnéz AM, Carneiro I: Plant based insect repellent and insecticide treated bed nets to protect against malaria in areas of early evening biting vectors: double blind randomised placebo controlled clinical trial in the Bolivian Amazon. BMJ 2007, 335:1023.

24. World Health Organization: Guidelines for the treatment of malaria. Secondth edition. World Health Organization: Geneva; 2010. http://whqlibdoc.who.int/ publications/2010/9789241547925_eng.pdf.

25. Santana Filho F, Arcanjo A, Chehuan YM, Costa MR, Martinez-Espinosa FE, Vieira JL, Barbosa M, Alecrim WD, Alecrim M: Chloroquine-resistant Plasmodium vivax, Brazilian Amazon. Emerg Infect Dis 2007, 13:1125-1126.

26. Gama BE, Lacerda MVG, Daniel-Ribeiro CT, Ferreira-da-Cruz MDF: Chemoresistance of Plasmodium falciparum and Plasmodium vivax parasites in Brazil: consequences on disease morbidity and control. Mem Inst Oswaldo Cruz 2011, 106:159-166. 
27. Van den Eede P, Soto-Calle VE, Delgado C, Gamboa D, Grande T, Rodriguez H, Llanos-Cuentas A, Anné J, D'Alessandro U, Erhart A: Plasmodium vivax sub-patent infections after radical treatment are common in Peruvian patients: results of a 1-year prospective cohort study. PLoS One 2011, 6:e16257.

28. Santana MS, de Lacerda MVG, Barbosa MDGV, Alecrim WD, Alecrim MDGC: Glucose-6-phosphate dehydrogenase deficiency in an endemic area for malaria in Manaus: a cross-sectional survey in the Brazilian Amazon. PLoS One 2009, 4:e5259.

29. Moyano M, Méndez F: Defectos eritrocíticos y densidad de la parasitemia en pacientes con malaria por Plasmodium falciparum en Buenaventura, Colombia. Rev Panam Salud Publica 2005, 18:25-32.

30. Dondorp AM, Fanello Cl, Hendriksen IC, Gomes E, Seni A, Chhaganlal KD, Bojang K, Olaosebikan R, Anunobi N, Maitland K, Kivaya E, Agbenyega T, Nguah SB, Evans J, Gesase S, Kahabuka C, Mtove G, Nadjm B, Deen J, Mwanga-Amumpaire J, Nansumba M, Karema C, Umulisa N, Uwimana A, Mokuolu OA, Adedoyin OT, Johnson WB, Shefu AK, Onyamboko MA, Sakulthaew T, Ngum WP, Silamut K, Stepniewska K, Woodrow J, Bethell D, Wills B, Oneko M, Peto TE, von Seidlein L, Day NP, White NJ, QUAMAT group: Artesunate versus quinine in the treatment of severe falciparum malaria in African children (AQUAMAT): an open-label, randomised trial. Lancet 2010, 376:1647-1657.

31. Charman SA, Arbe-Barnes S, Bathurst IC, Brun R, Campbell M, Charman WN, Chiu FC, Chollet J, Craft JC, Creek DJ, Dong Y, Matile H, Maurer M, Morizzi J, Nguyen T, Papastogiannidis P, Scheurer C, Shackleford DM, Sriraghavan K, Stingelin L, Tang Y, Urwyler H, Wang X, White KL, Wittlin S, Zhou L, Vennerstrom JL: Synthetic ozonide drug candidate OZ439 offers new hope for a single-dose cure of uncomplicated malaria. Proc Natl Acad Sci USA 2011, 108:4400-4405.

32. Bourdy G, Willcox ML, Ginsburg H, Rasoanaivo P, Graz B, Deharo E: Ethnopharmacology and malaria: new hypothetical leads or old efficient antimalarials? Int J Parasitol 2008, 38:33-41.

33. Wells TNC: Natural products as starting points for future antimalarial therapies: going back to our roots? Malar J 2011, 10:S3.

34. Bravo JA, Lavaud C, Bourdy G, Deharo E, Gimenez A, Sauvain M: Antimalarial activity of ormosanine and homoormosanine from Bowdichia virgiloides. Revista Boliviana de Quimica 2002, 19:12-17.

35. Deharo E, Bourdy G, Quenevo C, Muñoz V, Ruiz G, Sauvain M: A search for natural bioactive compounds in Bolivia through a multidisciplinary approach. Part V. Evaluation of the antimalarial activity of plants used by the Tacana Indians. J Ethnopharmacol 2001, 77:91-98.

36. da Silva Filho AA, Resende DO, Fukui MJ, Santos FF, Pauletti PM, Cunha WR, Silva ML, Gregório LE, Bastos JK, Nanayakkara NP: In vitro antileishmanial, antiplasmodial and cytotoxic activities of phenolics and triterpenoids from Baccharis dracunculifolia D. C. (Asteraceae). Fitoterapia 2009, 80:478-482.

37. de Andrade-Neto VF, Pohlit AM, Pinto AC, Silva EC, Nogueira KL, Melo MR, Henrique MC, Amorim RC, Silva LF, Costa MR, Nunomura RC, Nunomura SM, Alecrim WD, Alecrim M, Chaves FC, Vieira PP: In vitro inhibition of Plasmodium falciparum by substances isolated from Amazonian antimalarial plants. Mem Inst Oswaldo Cruz 2007, 102:359-365.

38. de Andrade-Neto VF, da Silva T, Lopes LM, Do Rosário VE, de Pilla Varotti F, Krettli AU: Antiplasmodial activity of aryltetralone lignans from Holostylis reniformis. Antimicrob Agents Chemother 2007, 51:2346-2350.

39. Kayano AC, Lopes SC, Bueno FG, Cabral EC, Souza-Neiras WC, Yamauchi LM, Foglio MA, Eberlin MN, Mello JC, Costa FT: In vitro and in vivo assessment of the anti-malarial activity of Caesalpinia pluviosa. Malar J 2011, 10:112.

40. Silva LF RE, Silva Pinto AC, Pohlit AM, Quignard EL, Vieira PP, Tadei WP, Chaves FC, Samonek JF, Lima CA, Costa MR, Alecrim M, Andrade-Neto VF: In vivo and in vitro antimalarial activity of 4-nerolidylcatechol. Phytother Res 2011, 25:1181-1188.

41. Pinto AC, Silva LF, Cavalcanti BC, Melo MR, Chaves FC, Lotufo LV, de Moraes MO, de Andrade-Neto VF, Tadei WP, Pessoa CO, Vieira PP, Pohlit AM: New antimalarial and cytotoxic 4-nerolidylcatechol derivatives. Eur J Med Chem 2009, 44:2731-2735.

42. Garavito G, Rincón J, Arteaga L, Hata Y, Bourdy G, Gimenez A, Pinzón R, Deharo E: Antimalarial activity of some Colombian medicinal plants. J Ethnopharmacol 2006, 107:460-462.

43. Debenedetti S, Muschietti L, van Baren C, Clavin M, Broussalis A, Martino V, Houghton PJ, Warhurst D, Steele J: In vitro antiplasmodial activity of extracts of Argentinian plants. J Ethnopharmacol 2002, 80:163-166.

44. Baelmans R, Deharo E, Bourdy G, Muñoz V, Quenevo C, Sauvain M, Ginsburg $\mathrm{H}$ : A search for natural bioactive compounds in Bolivia through a multidisciplinary approach. Part IV. Is a new haem polymerisation inhibition test pertinent for the detection of antimalarial natural products? J Ethnopharmacol 2000, 73:271-275

45. Flores $Y$, Vila J, Almanza GR: Secondary metabolites from Caesalpinia pluviosa. Revista Boliviana de Quimica 2006, 23:1-8

46. Ibáñez-Calero SL, Jullian $V$, Sauvain M: A new anthraquinone isolated from Rumex obtusifolius. Revista Boliviana de Química 2009, 26:49-56.

47. Muñoz V, Sauvain M, Bourdy G, Callapa J, Bergeron S, Rojas I, Bravo JA, Balderrama L, Ortiz B, Gimenez A, Deharo E: A search for natural bioactive compounds in Bolivia through a multidisciplinary approach. Part I. Evaluation of the antimalarial activity of plants used by the Chacobo Indians. J Ethnopharmacol 2000, 69:127-137.

48. Muñoz V, Sauvain M, Bourdy G, Callapa J, Rojas I, Vargas L, Tae A, Deharo E: The search for natural bioactive compounds through a multidisciplinary approach in Bolivia. Part II. Antimalarial activity of some plants used by Mosetene indians. J Ethnopharmacol 2000, 69:139-155

49. Muñoz V, Sauvain M, Bourdy G, Arrázola S, Callapa J, Ruiz G, Choque J, Deharo E: A search for natural bioactive compounds in Bolivia through a multidisciplinary approach. Part III. Evaluation Of the antimalarial activity of plants used by Alteños Indians. J Ethnopharmacol 2000, 71:123-131.

50. Costa ESS, Dolabela MF, Povoa MM, Oliveira DJ, Müller AH: Estudos farmacognósticos, fitoquímicos, atividade antiplasmódica e toxicidade em Artemia salina de extrato etanólico de folhas de Montrichardia linifera (Arruda) Schott, Araceae. Revista Brasileira de Farmacognosia 2009, 19:834-838.

51. da Silva Filho AA, Costa ES, Cunha WR, e Silva ML, Nanayakkara NP, Bastos JK: In vitro antileishmanial and antimalarial activities of tetrahydrofuran lignans isolated from Nectandra megapotamica (Lauraceae). Phytother Res 2008, 22:1307-1310.

52. Andrade-Neto VF, Brandão MG, Oliveira FQ, Casali WW, Njaine B, Zalis MG, Oliveira LA, Krettli AU: Antimalarial activity of Bidens pilosa L. (Asteraceae) ethanol extacts from wild plans collected in various localities or plants cultivated in humus soil. Phytother Res 2004, 18:634-639.

53. de Andrade-Neto VF, Brandão MGL, Stehmann LA, Krettli A: Antimalarial activity of Cinchona-like plants used to treat fever and malaria in Brazil. J Ethnopharmacol 2003, 87:253-256.

54. de Mesquita ML, Grellier P, Blond A, Brouard JP, de Paula JE, Espindola LS, Mambu L: New ether diglycosides from Matayba guianensis with antiplasmodial activity. Bioorg Med Chem 2005, 13:4499-4506.

55. Dolabela MF, Oliveira SG, Nascimento JM, Peres JM, Wagner H, Póvoa MM, de Oliveira $A B$ : In vitro antiplasmodial activity of extract and constituents from Esenbeckia febrifuga, a plant traditionally used to treat malaria in the Brazilian Amazon. Phytomedicine 2008, 15:367-372.

56. Estevam CS, Oliveira FM, Conserva LM, Lima LF, Barros ECP, Barros SCP, Rocha EMM, Andrade EHA: Constituintes químicos e avaliação preliminar in vivo da atividade antimalárica de Ouratea nitida Aubl (Ochnaceae). Rev Bras Farmacogn 2005, 15:195-198.

57. Fischer D, Gualda N, Bachiega D: In vitro screening for antiplasmodial activity of isoquinoline alkaloids from Brazilian plant species. Acta Trop 2004, 92:261-266.

58. Morais TR, Romoff P, Fávero OA, Reimão JQ, Lourenço WC, Tempone AG, Hristov AD, Di Santi SM, Lago JH, Sartorelli P, Ferreira MJ: Anti-malarial, anti-trypanosomal, and anti-leishmanial activities of jacaranone isolated from Pentacalia desiderabilis (Vell.) Cuatrec. (Asteraceae). Parasitol Res 2012, 110:95-101.

59. Oliveira FQ, Andrade-Neto V, Krettli AU, Brandão MGL: New evidences of antimalarial activity of Bidens pilosa roots extract correlated with polyacetylene and flavonoids. J Ethnopharmacol 2004, 93:39-42

60. Sá MS, de Menezes MN, Krettli AU, Ribeiro IM, Tomassini TC, Ribeiro dos Santos R, de Azevedo WF Jr, Soares MB: Antimalarial activity of physalins B, D, F, and G. J Nat Prod 2011, 74:2269-2272.

61. Uchôa VT, de Paula RC, Krettli LG, Goulart Santana AE, Krettli AU: Antimalarial activity of compounds and mixed fractions of Cecropia pachystachya. Drug Dev Res 2010, 71:82-91.

62. Loyola LA, Bórquez J, Morales G, San-Martín A, Darias J, Flores N, Giménez A: Mulinane-type diterpenoids from Azorella compacta display antiplasmodial activity. Phytochemistry 2004, 65:1931-1935.

63. Pabón A, Carmona J, Maestre A, Camargo M, Blair S: Inhibition of $P$. falciparum by Steroids Isolated from Solanum nudum. Phytother Res 2002, 62:59-62. 
64. Valadeau C, Pabon A, Deharo E, Albán-Castillo J, Estevez Y, Lores FA, Rojas R, Gamboa D, Sauvain M, Castillo D, Bourdy G: Medicinal plants from the Yanesha (Peru): evaluation of the leishmanicidal and antimalarial activity of selected extracts. J Ethnopharmacol 2009, 123:413-422.

65. Ruiz L, Ruiz L, Maco M, Cobos M, Gutierrez-Choquevilca AL, Roumy V: Plants used by native Amazonian groups from the Nanay River (Peru) for the treatment of malaria. J Ethnopharmacol 2011, 133:917-921.

66. Sperandeo NR, Brun R: Synthesis and biological evaluation of pyrazolylnaphthoquinones as new potential antiprotozoal and cytotoxic agents. Chembiochem 2003, 4:69-72.

67. da Silva AJM, Netto CD, Pacienza-Lima W, Torres-Santos EC, Rossi-Bergmann B, Maurel S, Valentin A, Costa PRR: Antitumoral, antileishmanial and antimalarial activity of pentacyclic 1,4-naphthoquinone derivatives. J Braz Chem Soc 2009, 20:176-182.

68. Charris J, Barazarte A, Domínguez J, Lobo G, Camacho J, Ferrer R, Gamboa $\mathrm{N}$, Rodrigues J: Synthesis and antimalarial activity of ethyl 3-amino-4-oxo9-(phenylsubstituted) thieno [2, 3-b] quinoline-2-carboxylate derivatives. $J$ Heterocyclic Chem 2007, 44:639-643.

69. Cunico W, Gomes CR, Facchinetti V, Moreth M, Penido C, Henriques MG, Varotti FP, Krettli LG, Krettli AU, da Silva FS, Caffarena ER, de Magalhães CS: Synthesis, antimalarial evaluation and molecular modeling studies of hydroxyethylpiperazines, potential aspartyl protease inhibitors, part 2. Eur J Med Chem 2009, 44:3816-3820.

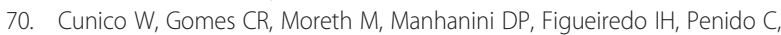
Henriques MG, Varotti FP, Krettli AU: Synthesis and antimalarial activity of hydroxyethylpiperazine derivatives. Eur J Med Chem 2009, 44:1363-1368.

71. Gnoatto SC, Susplugas S, Dalla Vechia L, Ferreira TB, Dassonville-Klimpt A Zimmer KR, Demailly C, Da Nascimento S, Guillon J, Grellier P, Verli H, Gosmann G, Sonnet P: Pharmacomodulation on the 3-acetylursolic acid skeleton: Design, synthesis, and biological evaluation of novel N-\{3-[4-(3aminopropyl)piperazinyl]propyl\}-3-O-acetylursolamide derivatives as antimalarial agents. Bioorg Med Chem 2008, 16:771-782.

72. de Sá MS, Costa JF, Krettli AU, Zalis MG, Maia GL, Sette IM, Câmara Cde A, Filho JM, Giulietti-Harley AM, Ribeiro Dos Santos R, Soares MB: Antimalarial activity of betulinic acid and derivatives in vitro against Plasmodium falciparum and in vivo in P. berghei-infected mice. Parasitol Res 2009, 105:275-279.

73. Pinheiro JC, Ferreira MMC, Romero OAS: Antimalarial activity of dihydroartemisinin derivatives against $P$. falciparum resistant to mefloquine: a quantum chemical and multivariate study. Science 2001, 572:35-44.

74. Barbosa LCA, Maltha CRA, Alvarenga E: Síntese e avaliação da atividade antimalarica de novos ozonideos. Eclética Química 2002, 27:1-9.

75. de Oliveira RB, de Souza-Fagundes EM, Soares RP, Andrade AA, Krettli AU, Zani CL: Synthesis and antimalarial activity of semicarbazone and thiosemicarbazone derivatives. Eur J Med Chem 2008, 43:1983-1988.

76. Camacho J, Barazarte A, Gamboa N, Rodrigues J, Rojas R, Vaisberg A, Gilman $R$, Charris J: Synthesis and biological evaluation of benzimidazole- 5 -carbohydrazide derivatives as antimalarial, cytotoxic and antitubercular agents. Bioorg Med Chem 2011, 19:2023-2029.

77. Corrales RC, de Souza NB, Pinheiro LS, Abramo C, Coimbra ES, Da Silva AD: Thiopurine derivatives containing triazole and steroid: synthesis, antimalarial and antileishmanial activities. Biomed Pharmacother 2011, 65:198-203.

78. Barazarte A, Lobo G, Gamboa N, Rodrigues JR, Capparelli MV, Alvarez-Larena A, López SE, Charris JE: Synthesis and antimalarial activity of pyrazolo and pyrimido benzothiazine dioxide derivatives. Eur J Med Chem 2009, 44:1303-1310.

79. Barazarte A, Camacho J, Domínguez J, Lobo G, Gamboa N, Rodrigues J, Capparelli MV, Alvarez-Larena A, Andujar S, Enriz D, Charris J: Synthesis, antimalarial activity, structure-activity relationship analysis of thieno-[3,2b]benzothiazine S, S-dioxide analogs. Bioorg Med Chem 2008, 16:3661-3674

80. Vellasco Junior WT, Guedes GP, Vasconcelos TR, Vaz MG, de Souza MV, Krettli AU, Krettli LG, Aguiar AC, Gomes CR, Cunico W: Synthesis and antimalarial activity of thioetherhydroxyethylsulfonamides, potential aspartyl protease inhibitors, Part 3. Eur J Med Chem 2011, 46:5688-5693.

81. Dominguez JN, Leon C, Rodrigues J, Gamboa de Dominguez N, Gut J, Rosenthal PJ: Synthesis of chlorovinyl sulfones as structural analogs of chalcones and their antiplasmodial activities. Eur J Med Chem 2009, 44:1457-1462.
82. Domínguez JN, León C, Rodrigues J, Gamboa de Dominguez N, Gut J, Rosenthal PJ: Synthesis and antimalarial activity of sulfonamide chalcone derivatives. Farmaco 2005, 60:307-311.

83. León C, Rodrigues J, Gamboa de Domínguez N, Charris J, Gut J, Rosenthal PJ, Domínguez JN: Synthesis and evaluation of sulfonylurea derivatives as novel antimalarials. Eur J Med Chem 2007, 42:735-742.

84. Arancibia R, Dubar F, Pradines B, Forfar I, Dive D, Klahn AH, Biot C: Synthesis and antimalarial activities of rhenium bioorganometallics based on the 4-aminoquinoline structure. Bioorg Med Chem 2010, 18:8085-8091.

85. Rojas Ruiz FA, García-Sánchez RN, Estupiñan SV, Gómez-Barrio A, Torres Amado DF, Pérez-Solórzano BM, Nogal-Ruiz JJ, Martínez-Fernández AR, Kouznetsov W: Synthesis and antimalarial activity of new heterocyclic hybrids based on chloroquine and thiazolidinone scaffolds. Bioorg Med Chem 2011, 19:4562-4573.

86. Charris JE, Domínguez JN, Gamboa N, Rodrigues JR, Angel JE: Synthesis and antimalarial activity of E-2-quinolinylbenzocycloalcanones. Eur J Med Chem 2005, 40:875-881.

87. Vashist U, Carvalhaes R, D'agosto M, da Silva AD: Antimalarial activity of the novel quinoline/6-thiopurine conjugate in Gallus gallus Linnaeus, infected experimentally by Plasmodium (Novyella) juxtanucleare. Chem Biol Drug Des 2009, 74:434-437.

88. de Souza NB, Carmo AM, Lagatta DC, Alves MJ, Fontes AP, Coimbra ES, da Silva AD, Abramo C: 4-aminoquinoline analogues and its platinum (II) complexes as antimalarial agents. Biomed Pharmacother 2011, 65:313-316.

89. Cunico W, Cechinel CA, Bonacorso HG, Martins MA, Zanatta N, de Souza MV, Freitas IO, Soares RP, Krettli AU: Antimalarial activity of 4-(5trifluoromethyl-1H-pyrazol-1-yl)-chloroquine analogues. Bioorg Med Chem Lett 2006, 16:649-653.

90. Rodrigues J, Charris J, Domínguez J, Ángel J, Gamboa N: Modification of oxidative status in Plasmodium berghei-infected erythrocytes by E-2-chloro-8-methyl-3-[(4'-methoxy-1'-indanoyl)-2'-methyliden]quinoline compared to chloroquine. Mem Inst Oswaldo Cruz 2009, 104:865-870.

91. Domínguez JN, Charris JE, Lobo G, Gamboa de Domínguez N, Moreno MM, Riggione F, Sanchez E, Olson J, Rosenthal PJ: Short communication Synthesis of quinolinyl chalcones and evaluation of their antimalarial activity. Eur J Med Chem 2001, 36:555-560.

92. Ferrer R, Lobo G, Gamboa N, Rodriques J, Abramjuk C, Jung K, Lein M, Charris JE: Synthesis of [(7-chloroquinolinyl-4-yl)amino]chalcones: potential antimalarial and anticancer agents. Sci Pharm 2009, 77:725-741.

93. Navarro M, Vásquez F, Sánchez-Delgado RA, Pérez H, Sinou V, Schrével J: Toward a novel metal-based chemotherapy against tropical diseases. 7 . Synthesis and in vitro antimalarial activity of new gold-chloroquine complexes. J Med Chem 2004, 47:5204-5209.

94. Domínguez JN, León C, Rodrigues J, Gamboa de Domínguez N, Gut J, Rosenthal PJ: Synthesis and evaluation of new antimalarial phenylurenyl chalcone derivatives. J Med Chem 2005, 48:3654-3658.

95. D de Andrade-Neto VF, Goulart MO, da Silva Filho JF, da Silva MJ, Pinto Mdo C, Pinto AV, Zalis MG, Carvalho LH, Krettli AU: Antimalarial activity of phenazines from lapachol, beta-lapachone and its derivatives against Plasmodium falciparum in vitro and Plasmodium berghei in vivo. Bioorg Med Chem Lett 2004, 14:1145-1149.

96. Hilário FF, de Paula RC, Silveira ML, Viana GH, Alves RB, Pereira JR, Silva LM, de Freitas RP, de Pilla Varotti F: Synthesis and evaluation of antimalarial activity of oxygenated 3-alkylpyridine marine alkaloid analogues. Chem Biol Drug Des 2011, 78:477-482

97. Rodrigues JR, Gamboa de Domínguez N: Plasmodium berghei: in vitro and in vivo activity of dequalinium. Exp Parasitol 2007, 115:19-24.

98. Burrows JN, Leroy D, Lotharius J, Waterson D: Challenges in antimalarial drug discovery. Future Med Chem 2011, 3:1401-1412.

99. Medicines for Malaria Venture; 2013 [www.mmv.org]

100. Dondorp AM, Nosten F, Yi P, Das D, Phyo AP, Tarning J, Lwin KM, Ariey F, Hanpithakpong W, Lee SJ, Ringwald P, Silamut K, Imwong M, Chotivanich K, Lim P, Herdman T, An SS, Yeung S, Singhasivanon P, Day NP, Lindegardh N, Socheat $D$, White $\mathrm{NJ}$ : Artemisinin resistance in Plasmodium falciparum malaria. N Engl J Med 2009, 361:455-467.

101. Cheeseman IH, Miller BA, Nair S, Nkhoma S, Tan A, Tan JC, Al Saai S, Phyo AP, Moo CL, Lwin KM, McGready R, Ashley E, Imwong M, Stepniewska K, Yi P, Dondorp AM, Mayxay M, Newton PN, White NJ, Nosten F, Ferdig MT, Anderson TJ: A major genome region underlying artemisinin resistance in malaria. Science 2012, 336:79-82. 
102. Noedl H, Socheat D, Satimai W: Artemisinin-resistant malaria in Asia. N Engl J Med 2009, 361:540-541.

103. Phyo AP, Nkhoma S, Stepniewska K, Ashley EA, Nair S, McGready R, Ler Moo C, Al-Saai S, Dondorp AM, Lwin KM, Singhasivanon P, Day NP, White NJ, Anderson TJ, Nosten F: Emergence of artemisinin-resistant malaria on the western border of Thailand: a longitudinal study. Lancet 2012, 379:1960-1966.

104. The malERA Consultative Group on Drugs: A research agenda for malaria eradication: Drugs. PLoS Med 2011, 8:e1000402.

105. Schmidt TJ, Khalid SA, Romanha AJ, Alves TM, Biavatti MW, Brun R, Da Costa FB, de Castro SL, Ferreira VF, de Lacerda MV, Lago JH, Leon LL, Lopes NP, Das Neves Amorim RC, Niehues M, Ogungbe IV, Pohlit AM, Scotti MT, Setzer WN, De NC Soeiro M, Steindel M, Tempone AG: The potential of secondary metabolites from plants as drugs or leads against protozoan neglected diseases - part I\&ll. Curr Med Chem 2012, 19:2128-2228.

106. Willcox ML, Graz B, Falquet J, Diakite C, Giani S, Diallo D: A "reverse pharmacology" approach for developing an anti-malarial phytomedicine. Malar J 2011, 10:S8.

107. Gamo FJ, Sanz LM, Vidal J, de Cozar C, Alvarez E, Lavandera JL, Vanderwall DE, Green DV, Kumar V, Hasan S, Brown JR, Peishoff CE, Cardon LR, GarciaBustos JF: Thousands of chemical starting points for antimalarial lead identification. Nature 2010, 465:305-310.

108. Guiguemde WA, Shelat AA, Garcia-Bustos JF, Diagana TT, Gamo FJ, Guy RK: Global phenotypic screening for antimalarials. Chem Biol 2012, 19:116-129.

109. Sanz LM, Crespo B, De-Cózar C, Ding XC, Llergo JL, Burrows JN, GarcíaBustos JF, Gamo FJ: Plasmodium falciparum in vitro killing rates allow to discriminate between different antimalarial mode-of-action. PLoS One 2012, 7:e30949.

110. Ding XC, Ubben D, Wells TNC: A framework for assessing the risk of resistance for anti-malarials in development. Malar J 2012, 11:292.

111. Delves M, Plouffe D, Scheurer C, Meister S, Wittlin S, Winzeler EA, Sinden RE, Leroy D: The activities of current antimalarial drugs on the life cycle stages of Plasmodium: a comparative study with human and rodent parasites. PLoS Med 2012, 9:e1001169.

112. Dembele L, Gego A, Zeeman AM, Franetich JF, Silvie O, Rametti A, Le Grand R, Dereuddre-Bosquet N, Sauerwein R, van Gemert GJ, Vaillant JC, Thomas AW, Snounou G, Kocken CH, Mazier D: Towards an in vitro model of Plasmodium hypnozoites suitable for drug discovery. PLoS One 2011, 6:e18162.

doi:10.1186/1475-2875-12-168

Cite this article as: Cruz et al:: Malaria in South America: a drug

discovery perspective. Malaria Journal 2013 12:168.

\section{Submit your next manuscript to BioMed Central and take full advantage of:}

- Convenient online submission

- Thorough peer review

- No space constraints or color figure charges

- Immediate publication on acceptance

- Inclusion in PubMed, CAS, Scopus and Google Scholar

- Research which is freely available for redistribution 